\title{
Capital Structure of Internet Companies: Case Study*
}

\author{
Zhenting Lee**, Shuting Liang**, Anton Miglo***
}

2014

\begin{abstract}
The financing decisions and capital structure of internet companies are analyzed and observed findings are related to the common capital structure theories. Large internet companies usually have low debt and small internet companies have high debt. It was found that the trade-off theory of capital structure, pecking order theory, market timing theory and other theories cannot individually explain a firm's capital structure. However, they can compliment each other in describing some patterns of observed behavior. A number of recommendations for capital structure theory and practice is suggested.
\end{abstract}

*For helpful suggestions and comments we are thankful to Sajal Dutta, Julian Dove, Benjamin Dilq, Jianfeng Lin, Sabilla Rafique and Milos Suljagic.

**University of Bridgeport. 126 Park Ave, Bridgeport, CT 06604.

***Nipissing University, 100 College Dr., North Bay, ON P1B 8L7

Key words: capital structure, internet companies, financing strategy, sources of financing 


\title{
Capital Structure of Internet Companies: Case Study
}

\begin{abstract}
The financing decisions and capital structure of internet companies are analyzed and observed findings are related to the common capital structure theories. Large internet companies usually have low debt and small internet companies have high debt. It was found that the trade-off theory of capital structure, pecking order theory, market timing theory and other theories cannot individually explain a firm's capital structure. However, they can compliment each other in describing some patterns of observed behavior. A number of recommendations for capital structure theory and practice is suggested.
\end{abstract}

\section{Introduction}

The modern theory of capital structure began with the famous proposition of Modigliani and Miller (1958) that described the conditions of capital structure irrelevance. Since then, many theories of capital structure have been developed including trade off theory, pecking order theory, agency cost theory, life cycle theory and flexibility theory. After so many innovations, capital structure remains one of the most controversial and debatable issue in corporate finance.

The key issues are as follows. First, an immense gap exists between theories and practice. Graham and Harvey (2001) found that less than 50\% of theoretical ideas find some support among managers. Second, there are big differences in the researchers' opinion. For example, Chirinko and Singha (2000), Leary and Roberts (2010) and Frank and Goyal (2003) claim that trade-off theory drives capital structure decisions while Shyam-Sunder and Myers (1999) and Lemmon and Zender (2010) claim that peckingorder theory drives capital structure. Third, there is difference among opinions about the direction that future work on capital structure should take. For instance, Harris and Raviv (1991) argue that asymmetric information theories of capital structure are not promising. However, the stream of research related to asymmetric information has not 
stopped since then. ${ }^{1}$ Furthermore, the financial crisis during 2008 and 2009 showed that corporate managers appeared to lack an understanding of the role of asymmetric information. The market for mortgage-backed securities, which many believe was at the core of financial crisis, involved asymmetric information between investors and issuers. Various scandals, such as the one involving Bernie Madoff, illustrate the depth of asymmetric information problems between firms’ insiders and investors.

The present paper attempts to analyze issues described above. The current practices of 71 companies including 29 large companies and 42 small companies were analyzed and compared to existing theories. ${ }^{2}$ The size of the companies is from 40 million to 223.48 billion. With the help of spreadsheet analysis an optimal capital structure for a given company was first found. Spreadsheet analysis is mostly based on the trade-off between tax advantages of debt and increasing risk from debt financing. This analysis implies that large companies in the Internet industry are underleveraged. For example, for Google Inc., the optimal debt ratio is $16.2 \%$ and the current debt ratio is just $8.8 \%$. It was also found that most small companies in the Internet industry are overleveraged. For example, the optimal debt ratio for Ediets.Com Inc is 0\%, but the current debt ratio is as high as $59.54 \%$.

Other factors that have not been taken into consideration in the spreadsheet analysis are then described, which affect managers' decisions on company's capital structure. It was found that no single theory of capital structure can explain the observed patterns of capital structure in internet industry. The trade-off theory of capital structure is unable to accurately explain why only a small fraction of firms that are increasingly profitable utilize debt as a source of financing. Spreadsheet analysis shows that firm's current capital structures are distant from their optimal. It was also found that the pecking order theory's prioritization of sources of financing is only maintained in certain situations. For example, it would appear that firms who undergo high-growth periods with net losses do not utilize public debt before equity financing. Most

\footnotetext{
${ }^{1}$ See, for example, Klein (2002) and Miglo (2010a, 2011).
}

${ }^{2}$ See Appendix 1. 
companies issued equity through an initial public offering before utilizing debt which opposes what is expected from the pecking order theory. The market timing theory pays tribute to some actions taken by nearly every firm in our sample. For example, nearly all companies issue equity through public offerings at opportune times, most notably during the "tech craze" or "dot.com bubble” of the late 1990s. Also it appears that firms undergo public offerings when the market has recovered from the tech crash of 2000 or at other times when management feels their stock is overvalued. Companies make stock repurchases at windows of opportunities where they believe their stock is undervalued. However, from a broader point of view, the market timing theory is limited in explaining firm's capital structure besides IPO decision.

Flexibility is largely unexplored area of capital structure that can explain many patterns of capital structure for internet industries. Both equity and debt holders do place value on flexibility, especially in the recent years of turmoil in capital markets. Internet companies seem to put an especial emphasis on flexibility when managing their capital structures given the innovative nature of their industry.

There is a "home bias" in capital structure for most companies in our sample. Internet companies can use international financing more efficiently. Some reasons for that include the availability of lower interest rates, flexible regulation for dynamic companies, no capitalization restrictions, reducing interest rate risk by using flexible interest rates in markets which have low correlation between each other, using modern financing arrangements like international project financing or non-recourse debt to mitigate agency problems.

It was found that small internet companies have high debt/equity ratios. This finding is related to recent line of research about the usage of debt by small companies (Robb and Robinson (2012), Cole and Sokolyk (2014) and Miglo (2014)). Using a lot of debt by small companies is inconsistent with almost any existing theory of capital structure. Some authors argue that recent findings about the importance of debt for small companies are opposite to common opinion that small businesses and especially start-ups rely heavily on internal finance including owner's equity or funds from 
relatives and friends. ${ }^{3}$

Credit rating concerns are unexplored area of capital structure theory. The capital structure management of large internet companies is strongly consistent with the view that managers are deeply concerned about ratings.

With regard to existing theories, the analysis revealed that any single theory has major problems in explaining capital structure management of internet companies. It suggests that a unified approach should be developed in near future. In addition, the opinion of Harris and Raviv (1991) that asymmetric information theories are less promising seems to be questionable. It would appear that asymmetric information is important in explaining many patterns of capital structure behavior but managers do not have a practical tool to use it more efficiently. At the same time given that the gap between theory and practice is very large, the same as Harris and Raviv (1991) in that the door is still widely open for new theory of capital structure which can be helpful to make a bridge between theory and practice of capital structure.

The rest of this paper is organized as follows. Section 2 describes internet industry. Section 3 presents a review of capital structure theories. Section 4 describes in details the analytical method used in the paper and the spreadsheet used to analyze firm's capital structure. Section 5 provides detailed examples of some firms capital structure analysis. Section 6 presents the results of firm's capital structure analysis and the conclusion is drawn in Section 7.

\section{The internet industry}

The internet started out as an American military project in the 1950-60s and has evolved into a modern mainstream phenomenon. It is used by common businesses for marketing and sales, for searching and sharing of files (including documents, audio and video files) by businesses and households, and it is even used to facilitate online communities with forums and "blogging" with popular websites such as Facebook, Twitter and Youtube. The Internet has

\footnotetext{
${ }^{3}$ See, for example, Robb and Robinson (2012).
} 
revolutionized the computer and communications world like nothing before. The Internet is at once a world-wide broadcasting capability, a mechanism for information dissemination, and a medium for collaboration and interaction between individuals and their computers without regard for geographic location. The Internet represents one of the most successful examples of the benefits of sustained investment and commitment to research and development of information infrastructure. Beginning with the early research in packet switching, the government, industry and academia have been partners in evolving and deploying this exciting new technology.

In the technology industry, one kind of the companies is pretty famous which is called information provider companies. It may sound unfamiliar for most people. However, most people are familiar with Internet search engine companies like worldwide Google, Yahoo, Baidu and so on. Many people probably depend on these internet search engine companies when they use internet to search. These internet search engine companies are also called information provider companies which provide different information to various customers. For instance, the famous search engine company Google can provide a tool to help customers to acquire wanted information. However, different information providers can provide different types of information. Like Youku, a video sharing website, can provide all types of videos information. With the development of the industry, new information provider companies like Facebook and LinkedIn can help people to establish connection and share information with others. In the information provider industry, companies provide information in different ways, but the basic concept is to provide the needed information to customers.

In the Internet industry, the leader companies and the laggards have the big difference in Market Cap, long term debt to equity, P/E, net profit margin and other aspects. For instance, the leader companies, Google, Yahoo and Baidu, have the market cap of $\$ 272.1 \mathrm{~B}, \$ 321.9 \mathrm{~B}$ and $\$ 380.4 \mathrm{~B}$. On the contrary, some small companies like, VRX Worldwide, Inc, Armada Data Corp, Alphinat Inc. have relatively small market cap of $\$ 1.0 \mathrm{M}$, \$1.8M and \$1.9M. P/E is also very different among different companies. For instance, Facebook that held its initial public offering (IPO) on May 18, 2012, has a P/E of 1805.33. Google has its P/E ratio of 25.62. Most of the big companies have 
high net profit margin. For instance, Google has the net profit margin of 20\%, and Yahoo has the similar net profit margin of 20.23\%. Compared to Google and Yahoo, Baidu has the highest net profit margin of $44.12 \%$. Small companies have the various net profit margin some companies have relatively high net profit margin. Atrinsic, Inc. has a market cap of $\$ 0.13 \mathrm{M}$ and has a net profit margin of $-36.7 \%$. eMedia Networks also has a relatively small market cap of $\$ 0.4 \mathrm{M}$. However, it has a quite different net profit margin of 11.59 compared with Atrinsic, Inc -36.7\%.

\section{Capital structure theories}

This section describes capital structure theories. It will discuss some challenges faced by each theory that provides a basic for further discussions about existing practices in capital structure theory and management. ${ }^{4}$

\subsection{Trade-off theory}

In contrast to dividends, interest paid on debt reduces the firm's taxable income. Debt also increases the probability of bankruptcy. Trade-off theory suggests that capital structure reflects a trade-off between the tax benefits of debt and the expected costs of bankruptcy (Kraus and Litzenberger, 1973). Miglo (2010) suggests a model where optimal debt level is given by the following:

$$
D=\frac{T \bar{R}}{T+k}
$$

Here $\bar{R}$ stands for maximal earnings, $\quad T$ is corporate tax rate and $k$ measures bankruptcy costs.

If $k$ is higher in (1), the equilibrium level of $D$ should be lower. As the expected bankruptcy costs increase, the advantages of using equity also increase. This result has several interpretations. Large firms should have more debt because they are more diversified and have lower default risk. Tangible assets suffer a smaller loss of value when firms go into distress. Hence, firms with more tangible assets should have higher leverage compared to those that have more intangible assets, such as research

\footnotetext{
${ }^{4}$ For a more detailed review of capital structure theory see, for instance, Miglo (2010b).
} 
firms. Growth firms tend to lose more of their value than non-growth firms when they go into distress. Thus, theory predicts a negative relationship between leverage and growth.

When $T$ increases in Equation 1, debt should also increase because higher taxes lead to a greater tax advantage of using debt. Hence, firms with higher tax rates should have higher debt ratios compared to firms with lower tax rates. Inversely, firms that have substantial non-debt tax shields such as depreciation should be less likely to use debt than firms that do not have these tax shields. If tax rates increase over time, debt ratios should also increase. Debt ratios in countries where debt has a much larger tax benefit should be higher than debt ratios in countries whose debt has a lower tax benefit.

As suggested in (1), if $\bar{R}$ increases, $D$ should also increase. Thus, more profitable firms should have more debt. Expected bankruptcy costs are lower and interest tax shields are more valuable for profitable firms.

Although trade-off theory predicts that the marginal tax benefit of debt should be equal to the marginal expected bankruptcy cost, the empirical evidence is mixed. Some researchers argue that the former is greater than the latter because direct bankruptcy costs are small and the level of debt is below optimal (Graham, 2000). Others find that indirect bankruptcy costs can total as much as 25 percent to 30 percent of assets value and are thus comparable with tax benefits of debt (Molina, 2005; Almeida and Philippon, 2007). Additionally, including personal taxation in the basic model can reduce the tax advantage of debt (Green and Hollifield, 2003; Gordon and Lee, 2007) because tax rates on the return from equity such as dividends or capital gain are often reduced.

Trade-off theory of capital structure is a foundation of spreadsheet analysis described in Section 4. The spreadsheet analysis takes into account taxes and also increasing risk from debt financing.

\subsection{Other theories of capital structure}

\subsubsection{Pecking-order theory.}


The key element of pecking-order theory is asymmetric information between firm's insiders and outsiders. Information asymmetries exist in almost every facet of corporate finance and complicate managers’ ability to maximize firm values. Managers of good quality firms face the challenge of directly convincing investors about the true quality of their firm especially if this concerns future performance. As a result, investors try to incorporate indirect evidence in their valuation of firm performance by analyzing information-revealing actions including capital structure choice.

Myers and Majluf (1984) set forth pecking order theory. Equity is dominated by internal funds in pecking order theory. Low-quality firms use equity as much as internal funds but high-quality firms prefer internal funds because shares issued by the company can only be sold with discount (i.e. below their true value) because of imperfect information problems. Similarly debt dominates equity. Debt suffers from miss valuation less than equity. The same holds if the firm has available assets-in-place. Hence a "pecking order” emerges: internal funds, debt, and equity (Myers and Majluf, 1984).

Good-quality firms tend to use internal funds for financing as much as possible. Because low-quality firms do not have as much profits and retained earnings as highquality firms, they use external sources, usually debt, more frequently. This helps to explain the described above puzzle about the negative correlation between debt and profitability.

Also pecking order theory predicts that a higher extent of asymmetric information reduces the incentive to issue equity.

\subsubsection{Signaling}

In the pecking order model, good quality firms have to use internal funds to avoid adverse selection problems and losing value. These firms cannot signal their quality by changing their capital structure. In signaling theory capital structure serves as a signal of private information (Ross, 1977). If a separating equilibrium exists, high-quality firms issue debt and low-quality firms issue equity. The empirical prediction is that firm value (or profitability) and the debt-to-equity ratio is positively related. The evidence, however, is ambiguous. Most empirical studies report a negative relationship between 
leverage and profitability as discussed earlier. In a similar spirit, some studies document the superior absolute performance of equity-issuing firms before and immediately after the issue (Jain and Kini, 1994; Loughran and Ritter, 1997). Several studies examine long-term firm performance following capital structure changes. Shah (1994) reports that business risk falls after leverage-increasing exchange offers but rises after leveragedecreasing exchange offers. Jain and Kini (1994), Mikkelson, Partch, and Shah (1997), and Loughran and Ritter (1997) document the long-run operating underperformance of equity issuing firms compared to non-issuing firms.

\subsubsection{Agency cost-based theories of capital structure}

Agency costs arise because managers do not necessarily act in the best interests of shareholders who also may not act in the best interests of creditors. Including agency costs in the basic model can help to explain some problems of trade-off theory discussed above such as debt conservatism.

If an investment yields large returns, equity holders capture most of the gains. If, however, the investment fails, debt holders bear the consequences. As a result, equity holders may benefit from investing in highly risky projects, even if the projects are value decreasing. Jensen and Meckling (1976) call this the "asset substitution effect.” Debt holders can correctly anticipate equity holders' future behavior. This leads to a decrease in the value of debt and reduces the incentive to issue debt. Myers (1977) observes that when firms are likely to go bankrupt in the near future, equity holders may have no incentive to contribute new capital to invest in value-increasing projects. Equity holders bear the entire cost of the investment, but the returns from the investment may be captured mainly by the debt holders (“debt overhang”).

On the other hand, some agency theories favor higher debt. For example, Jensen (1986) argues that debt improves the discipline of an entrenched manager (so called “debt and discipline” theory).

\subsubsection{Flexibility theory of capital structure and life cycle theory of capital structure.}

Firms in the development stage have little favorable track record (i.e., credit ratings) of borrowing (Diamond, 1991) and are most likely to be turned down for credit when they need it the most. Thus, firms in the development stage that have little 
financial flexibility will abstain from issuing risky debt and will instead issue equity. Firms in the maturity stage begin generating positive earnings and have more financial flexibility than developing firms. Accordingly, these firms rely more on debt financing to fund their investments as they face less financing constraints and as they expect to repay their debt with growing future earnings.

Flexibility theory finds some support in empirical studies (Byoun, 2008) and managers' surveys (Graham and Harvey, 2001). This theory helps to explain why small and risky firms issue equity and why these firms do not follow pecking-order theory. Gamba and Triantis (2008) develop a theoretical model that analyzes optimal capital structure policy for a firm that values flexibility in the presence of personal taxes and transaction costs. The importance of financial flexibility as compared to major theories of capital structure remains an open question. More work that compares flexibility theory with other theories is expected. Also it was noted that many young firms especially venture firms do not issue common equity but rather convertible preferred equity which resembles debt more than equity.

Life cycle theory of capital structure argues that besides financial flexibility there are other factors which can explain financing patterns of firms in different stages of their development (Damodaran, 2003). Start-up firms do not have much profit, so the tax advantage of debt is not as important as for a mature firm. The start-up firms do not require incentives for managers since there is no large separation between ownership and management like in the case of big public corporations. This leads to the idea that mature firms value debt more compared to start-up firms. To what extent the life cycle theory represents a separate theory of capital structure rather than a combination of arguments from other theories remains an open question.

\section{Method of research.}

The choice of case study approach is motivated by the following. First, there are a number of researchers calling for more case studies in capital structure management (Graham and Harvey, 2001). Second, case study is an effective way of research in areas 
which include several layers of analysis and different approaches and theories. Section 3 suggests that capital structure management represents such an area. There is a lot of competing theories of capital structure. Furthermore one of our main objectives is to find firms' optimal capital structure policies (as opposite to existing policies). Some of the theories are better formalized and make it more simple for managers to use in real life situations (such as trade-off theory) while others are far from that (such as asymmetric information). The case study is simply the best research strategy because the problem under study is to reach understanding in a complex context (Singleton, Straits, and Straits (1993), Mertens (1998)). Campbell (1989) advocates a case study design for investigating real-life events, including organizational and managerial processes. Third, available sample for capital structure management analysis of large companies is small so our sample covers a good fraction of firms.

Companies' capital structure was analyzed using the following questions (see Miglo (2012a) for more details).

1. What is the firm's current debt/equity ratio?

2. Is the firm's debt/equity ratio low or high compared with other firms at the same industry or related industries?

3. Is the firm's current debt/equity ratio explained by the firm's financial policy or by the current market conditions?

4. What is the firm's optimal capital structure according to WACC (weighted average cost of capital) approach?

5. If current debt/equity ratio different from optimal, then what factors, which are not taken into consideration in the spreadsheet analysis may explain this difference?

When working on above questions the spreadsheet analysis was used along with capital structure theories. These theories are Pecking-Order Theory, Trade-Off Theory, Agency Cost, Flexibility and some others described in previous chapter.

Questions 1, 2 and 4 deal with financial calculations. By doing so, the company's Debt/Equity Ratio and its WACC can be found. WACC is the expected return on all of a company's securities. It is calculated by multiplying the cost of each capital component by its proportional weight and then summing: 


\section{WACC $=(\mathrm{E} / \mathrm{V}) \mathrm{rE}^{+}(\mathrm{D} / \mathrm{V}) \mathbf{r D}(1-\mathrm{TC})$}

Here $\mathrm{D}$ and $\mathrm{E}$ are the market value of the firm's debt and equity, $\mathrm{V}=\mathrm{D}+\mathrm{E}$ is the firm's total market value, $\mathrm{r}_{\mathrm{D}}$ and $\mathrm{r}_{\mathrm{E}}$ are the cost of debt and equity, and $\mathrm{T}_{\mathrm{C}}$ is the marginal corporate tax rate. Tax is also taken into consideration, since interest paid on a firm's borrowing can be deducted from taxable income, which is the so called tax benefit.

To get the optimal capital structure, $\mathrm{D} /(\mathrm{D}+\mathrm{E})$ ratio changes from $0 \%$ to $100 \%$ as hypotheses, and several financial parameters for different ratios are calculated. Then we find one that has minimal WACC and respectively maximal market value for the firm.

More specifically, first $\beta$ is calculated

\section{$\beta=\left[1+\left(1-T_{C}\right) D / E\right] \beta_{0}{ }^{5}$}

Then, $\mathrm{r}_{\mathrm{E}}$ and $\mathrm{r}_{\mathrm{D}}$ are calculated by the following equations:

\section{$r_{E}=$ Current Short Term Government Rate $+\beta \times$ Risk Premium $r_{D}=$ Risk-Free Interest + Default Premium ${ }^{6}$}

Then, the WACC is calculated based on the equation above; all the WACC for different $\mathrm{D} /(\mathrm{D}+\mathrm{E})$ ratios are listed; and finally the minimum WACC from the list which corresponds to the optimal capital structure is found.

With regard to question 3, the firm's debt/equity ratio over the last few years is helpful. For example, the Oracle’s D/E ratio was growing from 2005 to 2008. With a further study, a part of the reason for the growing D/E ratio is Oracle’s financial policy, when the company aggressively purchased several competitors during that period and accumulated a large amount of debt.

As to question 5, the optimal debt/equity ratio (based on spreadsheet analysis) of eBay's is significantly higher than its current ratio. It appears that this happened because high bankruptcy cost of the industry and the needs for flexibility for future financing are not taken into consideration in the WACC approach. We hold the view of that eBay has invested so much money, time, and effort to develop specific products, that the

\footnotetext{
${ }^{5}$ This is Ito formula. $\beta_{0}$ refers to the "unlevered" beta of the company.

${ }^{6}$ Default premium depends on the company's credit rating that ranges from AAA to D. It depends in turn on such parameters as interest coverage ratio.
} 
consequence can be very serious if it fails due to a large amount of debt. The primary reason is the company's large proportion of intellectual property which cannot be quickly converted to cash in a financial distress situation. Moreover, the e-commerce industry is still in its growth stage, the future financing requirements of the industry are unknown, therefore issuing stocks to finance today's capital needs leaves firms with more flexibility for future financing than borrowing money.

It was also found that the agency cost for Microsoft is relatively low, and this can be explained by pointing out that the biggest shareholder of Microsoft - Bill Gates has been deeply involved in company's management. When there are fewer conflicts between managers and shareholders, there would be less agency cost.

An excel file was used that is divided into following parts ${ }^{7}$ : Inputs, Operating lease information, Debt, Tax rate, and Calculations. Inputs part has three components, financial information, market information, and general market data. Financial information includes earnings before interest, taxes and depreciation (EBITDA) and depreciation and amortization. Market information includes number of shares outstanding, market price per share, Beta of the company. Current long-term government bond rate, short-term interest rate, risk premium, and country default spread are in the general market data.

Operating lease expenses are really financial expenses, and should be treated as such. Accounting standards allow them to be treated as operating expenses. In this part, the commitments to make operating leases are converted into debt and the operating income is adjusted accordingly, by adding back the imputed interest expense on this debt.

In the debt part, each company's book value and market value of debt were found. In each kind of value, companies’ bank medium-term debt, bank long-term debt, bonds, unsecured debentures and notes, senior debt securities, senior medium-term notes, subordinated medium-term notes, and other notes are taken into the consideration. Then, based on firms' income statement, we find their earnings before tax and provision for

\footnotetext{
${ }^{7}$ For more details, see Appendix 2-6.
} 
taxes in the recent three years. Then the average tax rates in three years are calculated.

The calculation part includes the following parts:

1. Input data;

2. Interest coverage ratios, rating of debt, default spreads, interest rates and probabilities of default.

3. Current situation;

4. Capital structure and cost of capital calculation;

5. Main results.

Most data about the company (earnings, expenditures, depreciation etc.) were found from yahoo finance (http://finance.yahoo.com/) and edumarketinsight website (educational version of Standard and Poors data base) for which we had passwords provided together with textbooks (usually it was "Principles of corporate finance" by Brealey and Myers). Default spreads, risk premiums and other information for point 2 could be found on bondsonline website or on Federal Reserve website. ${ }^{8}$ Points 3-5 represent calculations.

Finally, several ratios were calculated such as $\mathrm{D} /(\mathrm{D}+\mathrm{E})$ ratio, Beta of the firm, cost of equity, cost of debt, WACC, market value of firm, and market price/share.

\section{Examples of company capital structure analysis}

Companies are divided into two groups, the large companies and the small companies. The large companies are market cap larger than 1 billion dollars (for example Google and Yahoo), and the small companies are market cap smaller than 1 billion dollars (for example Move and Look Smart). This section presents the analysis of these companies. The following tables show calculation results.

\subsection{Google}

Table 1. Results from Google Analysis 2013

\begin{tabular}{|c|c|c|c|}
\hline & $\begin{array}{c}\text { Current Capital } \\
\text { Structure }\end{array}$ & $\begin{array}{c}\text { Optimal Capital } \\
\text { Structure }\end{array}$ & Change \\
\hline $\mathrm{D} /(\mathrm{D}+\mathrm{E})$ Ratio & $4.02 \%$ & $10.01 \%$ & $5.99 \%$ \\
\hline
\end{tabular}

\footnotetext{
${ }^{8}$ http://www.bondsonline.com/Todays_Market/Corporate_Bond_Spreads.php and http://www.federalreserve.gov/releases/h15/data.htm
} 


\begin{tabular}{|c|c|c|c|}
\hline Beta for the Stock & 1.03 & 1.07 & 0.04 \\
\hline Cost of Equity & $10.06 \%$ & $10.51 \%$ & $0.45 \%$ \\
\hline Cost of Debt & $2.47 \%$ & $2.47 \%$ & $0.00 \%$ \\
\hline WACC & $9.76 \%$ & $9.70 \%$ & $-0.06 \%$ \\
\hline Firm Value (mln.) & 273458 & 274988 & 1,530 \\
\hline Value/share & 797 & 801 & 4.00 \\
\hline
\end{tabular}

Google is a success story. Google’s mission is to organize the world's information and make it universally accessible and useful for generations to come. Google has a vision of expanding their resources while keeping its edge in the market. The acquisitions of related newborns and continuous launches of diverse and unique products indicate its push for growth and profitability while utilizing all the available resources possible.

Google started its journey back in 1995 with having a garage office and ended up announcing Initial Public Offering of 19,605,052 shares of Class A common stock that took place on Wall Street on August 18, 2004 which was highly awaited decision for public and as a result, the company’s liquidity increased. On December 31, 2004, Google had \$2,132.3 million of cash, cash equivalents and marketable securities, compared to \$334.7 million and \$146.3 million at the year-ends of 2003 and 2002 respectively. Since this time Google has mainly held on to these additional cash flows holding over \$3.5 billion in cash and cash equivalents in 2005 and 2006 to the date when Google shares jumped to an all-time high above \$1,000 after the search engine giant reported a surge in mobile and video advertising that helped drive quarterly revenue up 23 percent in 2013.

\section{Capital structure}

Google uses more equity financing rather than debt financing as it evolved from introductory to growing stage over the years. Google changed its debt/assets ratio from 4.7\% to 8.4\% during 2010 and 2012 and now back to the $4.02 \%$ in 2013 (see Table 1). Google's cash flow and profit are so strong that they can finance the business with retained earnings.

Trade off theory states that the capital structure is the result of a trade-off between the tax advantage of debt and higher risk and bankruptcy costs resulting from debt 
financing. Spreadsheet analysis suggests that Google's optimal debt ratio is $10.01 \%$, however, its current debt ratio is $4.02 \%$.

The pecking order theory implies that the company should use internal funds before using debt and equity and should use external debt before external equity. Google uses internal funds and equity but not debt which means Google considered going for IPO before debt which contradicts the pecking order theory. Second, this theory implies negative correlation between debt and profitability which is true as Google is making profit although not using a lot of debt. At the time of IPO, Google had enough profits to keep its operation running but still, rather taking more debt, Google decided to gather funds through equity. The reasons for Google to go public were these in accordance with "Letter from the Founders," published in 2010. It follows from that document that Google could restructure to get back below 500 shareholders (meaning, essentially, find a way to buy back shares from our employees) or it could continue to be a private company but at the same time live with having to report its financial results like any public company or it could go public. The latter will help to create a market for firm shares including shares belonging to employees.

On one hand, the agency cost theory favors low debt implying low bankruptcy cost and high level of confidence for investors. This is consistent with Google's policies. On the other hand, the agency cost theory states higher debt is good for a company because it can stimulate manager to perform better. This part is not consistent with Google case. In Google’s case, the conflict between shareholders and managers has low importance as the company is very profitable. In the long term the things may change. An important indicator of potential conflict between shareholders and managers is the fraction of shares owned by managers. In Google case it is 4\% (see Table 2) that is much smaller than for example in Microsoft case. At the same the total number of shareholders is quite large. It appears that Googles use partial ownership in terms of involvement of employees in shareholdings as a tool to motivate personnel to perform efficiently instead of external pressure by creditors. Although by issuing shares Google might be sharing ownership with different groups of people, but it is avoiding the risk to let go company's control in few hands. The conflict between creditors and 
shareholders is not likely to happen because Google has less concern for creditors issue as it has less debt. According to the Google policy, the board of directors has an obligation to Monitor and Manage Potential Conflicts of Interest. The Board will also ensure that there is no abuse of corporate assets or unlawful related party transactions. One of the reasons why Google wanted to go public rather than using debt could be to have fewer conflicts between company and outsiders.

Table 2. Information about Google.

\begin{tabular}{|l|c|}
\hline Equity & GOOG \\
\hline Market Cap (Mln.) & 285,019 \\
\hline \# of Institution Owners & 2,800 \\
\hline \# of Fund Owners & 4,574 \\
\hline \% Owned by Institutions & 72.63 \\
\hline \% Owned by Funds & 38.47 \\
\hline \% Owned by Insiders & 0.04 \\
\hline
\end{tabular}

As the flexibility theory and life cycle theory propose it is not beneficial for new firms to use debt financing, they rely more on equity to make their operations smooth at early stage of their existence so they are considered more flexible. Google expansion and growth business approach requires a lot of funds. Google historically pays cash for acquisition and expansion (except YouTube deal). The initial public offering in August of 2004 raised \$1,161.1M to help the company growth. The performance of Google while using equity as core source of financing became better since 2004. In 2004 Google has 170, 601 shares valued at \$34M and in 2005, Google acquired nine companies and all of the assets of another six other companies for a total amount of $\$ 130.5 \mathrm{M}$ of cash. Google continued with the acquisition of YouTube in 2008, AdMob in 2010, Zagat in 2011, Motorola Mobility in 2012 and Waze in 2013.

According to life cycle theory for growing and mature firms it is more likely to have higher leverage ratio which would result in low flexibility. It is opposite in Google's case as it does not use a lot of debt. The Debt/equity ratio for Google in 2004 was higher than in 2013.

The signaling theory states that from the investors' perspective, the market reaction 
on issuance of debt is neutral and of equity is negative. In Google's case, the issuance of shares at different stages made it successful and profitable so it's a different outcome of the signaling theory.

http://www.linkedin.com/today/post/article/20130913153717-7298-when-google-went-public

\subsection{Yahoo! Inc.}

Table 3. Results from Yahoo Analysis 2013

\begin{tabular}{|l|c|c|c|c|c|c|}
\hline & $\begin{array}{l}\mathrm{D} / \mathrm{D}+\mathrm{E}) \\
\text { Ratio }\end{array}$ & $\begin{array}{l}\text { Beta for } \\
\text { the } \\
\text { Stock }\end{array}$ & $\begin{array}{l}\text { Cost of } \\
\text { Equity }\end{array}$ & $\begin{array}{l}\text { Cost of } \\
\text { Debt }\end{array}$ & WACC \% & $\begin{array}{c}\text { Market Value of } \\
\text { Firm }\end{array}$ \\
\hline $\begin{array}{l}\text { Current } \\
\text { capital } \\
\text { structure }\end{array}$ & $6.30 \%$ & 0.92 & $8.33 \%$ & $1.04 \%$ & 7.87 & 39369059976 \\
\hline $\begin{array}{l}\text { Optimal } \\
\text { capital } \\
\text { structure }\end{array}$ & $25.00 \%$ & 1.07 & $9.41 \%$ & $2.14 \%$ & 7.59 & 40814194602 \\
\hline & $18.70 \%$ & 0.15 & $1.08 \%$ & $1.10 \%$ & 0.28 & 1445134,626 \\
\hline
\end{tabular}

Yahoo first appeared online in 1994 while the company’s founders, David Filo and Jerry Yang, were still students at university. The Company was later incorporated in March 1995 and completed its initial public offering on April 12 1996. Yahoo is the second largest firm in the internet information providers industry and is the main rival of the industry leader Google. Yahoo currently is a highly profitable and established company.

The big internet companies like Yahoo started life conservatively, preferring to avoid debt and use the enormous amount of free cash flow that their businesses throw off every year to grow their businesses.

\section{Is Yahoo's current debt/equity ratio high or low?}

Yahoo! Inc.'s debt/equity ratio is low. Yahoo! Inc. currently has a debt/equity ratio of $6.3 \%$ and their optimal ratio is around $25 \%$. Google has a debt/equity ratio of $4.02 \%$ and Microsoft has $20.24 \%$.

2. Is Yahoo's current debt/equity ratio explained by the firm's financial policy or by the 
current market conditions?

Yahoo's debt/equity is affected by both their policy and market conditions. Between 2004-2010 Yahoo’s debt/equity ratio was relatively stable though economic conditions were significantly changing. This suggests that Yahoo's debt/equity ratio is affected by its financial policy. The last time Yahoo! Inc. had a significantly higher debt/equity ratio was in 2003-2004. Around that time internet companies were recovering from the dot-com bubble bursting. So it is reasonable for a company to have a shortage of funds and to use debt to stay afloat. Also it appears that Yahoo! Inc. was competing heavily with Google at that time and acquired a few companies in order to improve their services. Also as the economy was recovering from 2010 onward the debt/equity ratio has had a slight downward trend. This suggests that debt/equity ratio is also affected by market conditions. As the economy improves, companies' earnings typically increase and debt/equity ratio decreases.

\section{Optimal capital structure analysis.}

As was mentioned above Yahoo! Inc. is underleveraged. There are many factors that are not taken into consideration in the spreadsheet that will affect the capital structure policy of the firm. Factors such as comparative firms, control problems, life cycle, and debt \& discipline theory do not explain Yahoo! Inc.’s capital structure. Most of firms in related industries have a higher debt/equity ratio than Yahoo! Inc. In terms of life cycle Yahoo is a mature firm and is not so risky anymore and therefore could have higher debt. The debt and discipline theory could work because most of Yahoo! Inc. shareholders are outsiders unlike Microsoft. Nevertheless, Yahoo! Inc. has very low debt and it is clear they are not using debt to stimulate their managers. Managers in the firm seem to be adequately responsive to Yahoo stockholders. The firm set up and email alert system, which gives investors alerts and instant access to all the company’s financial information and events. Upon signing up for these alerts, investors will be notified when any important press releases are made public, all SEC filings, including quarterly and annual reports and large insider transactions, and any webcasts or events that Yahoo holds such as financial conferences and stockholder's meetings. Yahoo also allows investors the ability to sign up to have all SEC filings, such as the 
10-K, annual reports and Proxy statements printed and mailed to their household so they have hardcopies of the information.

However, factors like intangible assets, flexibility, and pecking-order theory can help to explain Yahoo’s policy. Since a good portion of Yahoo! Inc.'s assets are intangible it has a higher risk and higher bankruptcy costs. The company should not have as much debt as other companies with more tangible assets. This could be one reason that explains Yahoo! Inc.'s lower than optimal debt/equity ratio. Also Yahoo has made good investments in the past, which was only possible because of the flexibility the company had. Yahoo! Inc. has bought and resold several companies. One of the most recent and successful investment projects was the investment in Alababa Group.

The pecking-order theory could explain why it does not have much debt. According to the pecking-order theory managers prefer to use internal funds to finance investments if possible over debt and equity. Therefore if the company had enough internal funds to support its investments it never had much need for debt.

Yahoo has other deductions to reduce the tax bite. The main one being depreciation of \$481M. This might be another reason as to why Yahoo! Inc. has decided to not take so much debt. The depreciation definitely helps to soften the effect of taxes. Following the trade-off theory Yahoo! Inc. might believe that their tax shield is sufficient and their risk of bankruptcy is too costly and outweighs the use of more debt.

How easy is it for bondholders to observe what equity investors are doing? Are the assets tangible or intangible? If not, what are the costs in terms of monitoring stockholders or in terms of bond covenants?

It is relatively easy for bondholders to observe what equity investors are doing because the information is easily found in the $10-\mathrm{K}$ and the other quarterly reports. The firm has both tangible and intangible assets. According to the company’s balance sheet, goodwill and intangible assets account for $\$ 5,132,210,000$ of their total $\$ 14,905,795,000$ worth of assets so there is a fairly even breakdown of intangible and tangible assets. Throughout 2012, Yahoo continued to purchase more intangible assets, such as intellectual property rights and developed technology, which saw amortization 
expenses for the company rise $7 \%$ compared to the year before.

How well can this firm forecast its future investment opportunities and needs? How much does it value flexibility?

The firm values flexibility very much. As recently as the end of the third quarter of 2013, Yahoo generated free cash flow of \$249 million and returned an additional \$1.7 billion to shareholders through buybacks. Their balance sheet had $\$ 3.2$ billion in cash and securities, which made them well positioned with ample liquidity to fund future investments for growth. Yahoo has more than $\$ 4.5$ billion dollars of long-term investments alone according to their balance sheet for the end of quarter three. With more than $\$ 3.2$ billion in cash and securities, they have a lot of financial flexibility should any good opportunities arise for them to make smart investments regarding their future.

\section{Recommendations regarding firm's capital structure.}

The main recommendation regarding the firm's capital structure is to add more debt. Following the idea that debt does indeed add discipline to a company and to the company's managers, Yahoo has room to add more debt and still be able to deal with it comfortably, while it gives them incentive to work harder, invest smarter and grow more rapidly in the future. Looking at Yahoo's total debt of roughly $\$ 121,000,000$ and comparing that to companies in the same industry, such as Microsoft and Google, who have debts of \$16 billion and \$7 billion dollars respectively, Yahoo’s debt is far less than both of them. From seeing the rapid growth of Google into one of the largest companies in the world, with a stock price of over $\$ 1,000$, Yahoo may want to look into a larger debt as that may be one of the reasons why Google is growing at such a rapid pace and why their stock prices have skyrocketed in recent times.

Of course there would be negative results that come from raising the debt as well (especially if debt is raised by too much), such as higher risk of bankruptcy (higher bankruptcy costs), less flexibility. In addition, too much debt could lead to problems like debt overhang. All considered it appears that the benefits outweigh the risks and Yahoo! Inc. needs to use more debt as part of the capital structure.

\subsection{Look Smart.}


Table 4. Results for LookSmart.

\begin{tabular}{|l|c|c|c|c|c|c|}
\hline & $\begin{array}{l}\text { D/(D+E) } \\
\text { Ratio }\end{array}$ & $\begin{array}{l}\text { Beta for the } \\
\text { Stock }\end{array}$ & $\begin{array}{l}\text { Cost of } \\
\text { Equity }\end{array}$ & $\begin{array}{l}\text { Cost of } \\
\text { Debt }\end{array}$ & WACC & $\begin{array}{c}\text { Market Value of } \\
\text { Firm (mln) }\end{array}$ \\
\hline $\begin{array}{l}\text { Current } \\
\text { capital } \\
\text { structure }\end{array}$ & $22.02 \%$ & 0.84 & $9.03 \%$ & $13.53 \%$ & $10.02 \%$ & 18 \\
$\begin{array}{l}\text { Optimal } \\
\text { capital } \\
\text { structure } \\
\text { Change }\end{array}$ & $0.00 \%$ & 0.66 & $7.13 \%$ & $3.27 \%$ & $7.13 \%$ & 25 \\
\hline
\end{tabular}

LookSmart, Ltd. (“LookSmart” or the "Company”) is a search and display advertising network solutions company that provides relevant solutions for search and display advertising customers. LookSmart was organized in 1996 and is incorporated in the State of Delaware

In December 1997, the Company approved the 1998 Stock Option Plan (the "Plan”). In June 2007, the stockholders approved the LookSmart 2007 Equity Incentive Plan (the “2007 Plan”). Under the 2007 Plan, the Company may grant incentive stock options, nonqualified stock options, stock appreciation rights and stock rights to employees, directors and consultants. Share-based incentive awards are provided under the terms of these two plans.

The Company's Plans are administered by the Compensation Committee of the Board of Directors. Awards under the Plans principally include at-the-money options and fully vested restricted stock. Outstanding stock options generally become exercisable over a four year period from the grant date and have a term of seven years. Grants can only be made under the 2007 Plan. The 1998 Plan is closed to further share issuance. The number of shares reserved for issuance under the Plans was 4.1 million and 4.3 million shares of common stock for the years ended December 31, 2012 and 2011, respectively. There were 1.9 million shares available to be granted under the 2007 Plan at December 31, 2012. At the same time, the company doesn’t have long time debt.

Like other small firms LookSmart is "damaged" in that they are struggling to 
survive. LookSmart is plagued with cutbacks, legal actions and loss of their consumer base which lower revenues and increase expenses. This company is very high in risk and has very little support from potential investors and creditors. These companies have little access to loans and have exhausted their equity opportunities and must survive through private placements which are low in cost and custom-designed for the company.

\subsection{Rediff.com}

Table 5. Results for Rediff.com

\begin{tabular}{|l|c|c|c|c|c|c|}
\hline & $\begin{array}{l}\mathrm{D} /(\mathrm{D}+\mathrm{E}) \\
\text { Ratio }\end{array}$ & $\begin{array}{l}\text { Beta for the } \\
\text { Stock }\end{array}$ & Cost of Equity & Cost of Debt & WACC & $\begin{array}{c}\text { Market Value } \\
\text { of Firm (mln.) }\end{array}$ \\
\hline $\begin{array}{l}\text { Current } \\
\text { capital }\end{array}$ & & & & & & \\
structure & $1.42 \%$ & 4.85 & $50.58 \%$ & $13.71 \%$ & $50.05 \%$ & 102 \\
$\begin{array}{l}\text { Optimal } \\
\text { capital }\end{array}$ & & & & & & \\
structure & $0.00 \%$ & 4.78 & $49.86 \%$ & $3.32 \%$ & $49.86 \%$ & 102 \\
Change & $-1.42 \%$ & -0.07 & $-0.72 \%$ & $-10.39 \%$ & $-0.19 \%$ & $\$ 0$ \\
\hline
\end{tabular}

For small business in international information provider industry, Rediff debt/equity ratio is higher than optimal. It appears that small businesses almost do not have much profit, so they think they have to borrow funds. However, the tax advantage of debt is not as important as for a big firm. And comparing with debt financing, there are more advantage in equity financing like less bankruptcy cost, less agency cost, more financing flexibility.

In fact, revenue of many small companies in international information provider industry is not enough to pay for his financing cost. In my opinion, it is very important to make sure that you can earn enough money to pay for your financing payment.

\subsection{Some other observations}

Small companies such as Paid, Move and Dynamic Leisure use different capital structures. Paid, Inc. engaged in multiple long-term convertible notes to help fund the development and launch of a new service which will provide them enough revenue so 
they need not outsource for future financing. Move uses long-term debt for long-term capital leases and Dynamic Leisure Corp. was bought out by another company which took out a long-term loan shortly after to fund a growth-through-acquisition strategy. All three companies struggle to earn profits or have none at all which makes risky companies that do not benefit by the trade-off associated with debt financing. Creditors are in the business to make money from lending theirs and are not interested in making risky or faulty investments. Debt-financing opportunities for Paid, Move and Dynamic are limited and costly and may hinder their future operations through putting strains on cash flows and restricting investments.

It can be observed that many of these small companies in their infancy stages are undergoing rapid growth and with it, large losses as all funds are being tunneled into investments and development. These companies bankruptcy costs outweigh tax benefits for potential loans the debt will be associated with high interest rates and restrictive covenants to protect the creditors. Secondly, a small number of the firms are "damaged" in that they are struggling to survive. Some of these companies such as LookSmart are plagued with cutbacks, legal actions and loss of their consumer base which lower revenues and increase expenses. Aptimus and others suffered during the tech crash of early 2000 which diminished the value high expectations for some of the firms. These companies are very high in risk and have very little support from potential investors and creditors. These companies have little access to loans and have exhausted their equity opportunities and must survive through private placements which are low in cost and custom-designed for the company.

\section{Summary of Analysis and Recommendations}

1. Our analysis shows that most large companies in the Internet industry are underleveraged. Low debt ratio is hurting the companies’ profitability. In recent years some companies began to realize that using tax shields can be beneficial. However, they use other ideas than debt tax shield. Google, for instance, has been paying taxes in countries with lower tax rates for last 4 years. It appears that one of the reasons why managers do not use debt tax shield is that they think that the capital cost of using 
internal funds is lower than issue debt. Based on this view, managers will overuse the internal funds. For those companies, our recommendation will be issue more debt to increase the companies' profitability. There are also some natural reasons for not using debt. These may include agency cost of debt and loss of flexibility. However, many companies are underleveraged even taking other factors into consideration.

2. Most small companies in the Internet industry are overleveraged. So they should have less debt. For some small companies, the cost of issuing new equity is naturally very high (asymmetric information problems). However, many companies underestimate long-term problems of carrying too much debt mostly flexibility loss. A possible solution would be using more preferred stocks.

3. Third, internet companies can use international financing more efficiently. International debt has advantages not just for governments but for corporations and individuals as well. Corporations can raise international debt in different currencies. The currency differential does not just diversify risk; it helps to shop for lower interest rates in a limitless international market. Rates in international markets are normally lower than domestic sources of capital. This is largely because there are many major firms and banks involved in these transactions, creating an inherent stability in the market. In addition, given the fact that there are many currencies involved in many transactions, the overall risk is lower to the lending institution, since any fluctuations in the currencies and the local markets are balanced out by the others. Also international market have greater flexibility. International capital markets like euro-currency are under no capitalization restrictions. This means there are no required reserves for all institutions to maintain to cushion their risk. As a result, these markets can lend 100 percent of their deposits, which is possible given the lack of risk in comparison to purely domestic institutions. Given the fact that international trade continues to grow, international markets continue to appear as a good bet to hedge against the possibility of local currency appreciation or market recessions. Finally, access to global capital markets can allow a firm to reduce its cost of capital. Companies seek a lower cost of capital through mergers and acquisitions, foreign direct investment, and other global activities. A competitive cost of capital depends on firm-specific characteristics that 
attract international portfolio investors and the liberalization of markets where companies have the freedom to source capital in liquid markets.

4. Using one theory cannot explain all capital structure strategies of Internet industry companies. Multiple theories should be used to explain the capital structure in this industry. One of findings of our research is that the optimal capital structure determined by the trade-off theory (spreadsheet analysis) usually differs from the actual financing mix that has observed in the industry. The pecking order theory can explain why small firms with no large cash reserves prefer debt to equity and why wellestablished and financially healthy firms do not use external financing. It fails to explain, however, why most companies (especially young and/or growing companies with large expansionary expenditures) prefer large equity issues to bond issues or even other types of debt. Signaling theory of capital structure cannot explain why most internet firms do not use debt as a signal of firm quality. The market timing hypothesis provides good explanations for timing of firms IPOs. For example, nearly all companies issue equity through public offerings at opportune times, most notably during the "tech craze” or "dot.com bubble” of the late 1990s. One can see that firms undergo public offerings when the market has recovered from the tech crash of 2000 or at other times when management feels their stock is overvalued. Companies make stock repurchases at windows of opportunities where they believe their stock is undervalued. However, from a broader point of view, the market timing theory is limited in explaining firm's capital structure besides IPO decision.

5. Flexibility is underexplored area. Both equity and debt holders do place value on flexibility, especially in the recent years of turmoil in capital markets. Managers' surveys show that managers value flexibility when choosing their capital structures. Therefore, new quantitative approaches in valuing flexibility should be developed. Managers are also concerned about credit ratings, as observed anecdotally in the press and through survey results. Future capital structure research would benefit from including credit ratings as part of the capital structure framework, to obtain a more comprehensive depiction of capital structure behavior.

6. Traditional Theories have a lot of room for improvement. The pecking order theory 
cannot explain why many firms in internet industry do not prefer debt over equity. Recent papers about dynamic pecking order theory are promising where managers may sometime find attractive to issue equity (see, for example, Miglo (2007, 2012b)). Next, one needs to develop Dynamic versions of Trade-Off Theory of Capital structure. Constructing models that recognize the role of time requires specifying a number of aspects that are typically ignored in a single-period model. Of particular importance are the roles of expectations and adjustment costs.

In the future, financial economists need to continue developing dynamic versions of each theory or to develop new models that incorporate both trade-off and pecking order ideas. More research may be required to create new models that can compete with tradeoff and pecking order theories.

7. Finally, a popular line of inquiry based on surveys of managers about their capital structure decisions seems to be promising. For example, Graham and Harvey (2001) report a large gap between theory and practice.

8. In terms of debate about future development of capital structure theory, the opinion of Harris and Raviv (1991) that asymmetric information theories are less promising seems to be questionable. Moreover, existing asymmetric information theories are not sufficient and this is the reason why these theories have less support than the trade-off theory among managers and students (Miglo, 2012a). However, asymmetric information is important in explaining many patterns of capital structure behavior of internet companies but managers do not have a practical tool to use it more efficiently. At the same time given that the gap between theory and practice is very large, we agree with Harris and Raviv (1991) opinion in that the door is still widely open for a new theory of capital structure.

\section{Other related issues}

1. Financial analysis of internet companies

Capital structure analysis is only a part (although a very important part) of firm's financial analysis. Surprisingly enough we have not found enough articles or case study analysis related to financial analysis of internet companies. So it appears that this 
direction is interesting for future research. In early 2000s a number of research related to financial analysis of internet companies was published which was mostly related to internet bubble of 1999, internet companies valuation etc. Current analysis would probably be focused with accessing the success factors of internet companies given that they have been doing quite well in recent years.

A closely related area to capital structure is the area of financing ideas and financing innovations. In early 2000s a popular topic was IPOs by internet companies. It seems like now a peer-to-peer financing becomes quite popular. ${ }^{9}$ Our research is related because growing amounts of peer-to-peer financing can explain high debt/equity ratios for small companies.

2. Combining financial and non-financial analysis of internet companies.

Capital structure is one of those financial topics which is closely related to other aspects of firms' activities such investments, production, strategic management, human resources management including agency problems etc. The case studies looking at different aspects of internet companies and their connections to capital structure policies are an interesting line for future research.

3. Educational research.

The topic of capital structure is a very interesting and important topic for conducting research in education area. It is not only related to the capital structure education itself, but also to general business education. Since capital structure is well connected with other areas of business, incorporating this in business classes and advanced business classes can be an interesting program. As a result, research is vital to see the result of this practice. For an example, see Miglo (2012a).

\section{Conclusions}

This project analyzes the financing decisions and capital structure of Internet companies and relates observed findings to the common capital structure theories. Large Internet companies usually have low debt and small internet companies have high debt. It would

\footnotetext{
${ }^{9}$ See, for example, Lin, Prabhala, and Viswanathan (2009).
} 
appear that the trade-off theory of capital structure, pecking order theory, market-timing theory, and other theories cannot individually determine a firm's capital structure and their use of sources of financing accurately but can compliment each other to help explain observed behavior. Our team also suggests a number of recommendations for capital structure theory and practice.

\section{REFERENCES}

Almeida, Heitor, and Thomas Philippon, 2007, The Risk-adjusted Cost of Financial Distress, Journal of Finance 62(6), 2557-2586.

Brealey, R. A, Stewart C. \& Myers F. A. (2006). Principles of Corporate Finance ( ${ }^{\text {th }}$ Ed.) NY: McGraw-Hill/Irwin

Byoun, Soku, (2008), Financial Flexibility and Capital Structure Decision, working paper. Available at SSRN: http://ssrn.com/abstract=1108850

Campbell, D. E. \& Kelly, J. S. Social Choice and Economic Theory. The American Economic Review 84 (2): 422-42

Chirinko, Robert, and Anuja Singha, (2000), Testing Static Trade-off Against Pecking Order Models of Capital Structure: A Critical Comment, Journal of Financial Economics 58(3), 417-425.

Cole, R., and T. Sokolyk, 2014, Debt Financing, Survival, and Growth of StartUp Firms, European Financial Management Journal, forthcoming.

Damodaran, Aswath. Corporate Finance: Theory and Practice (Wiley Series in Finance), 2003.

Diamond, Douglas W, (1991), Monitoring and Reputation: The Choice between Bank Loans and Directly Placed Debt, Journal of Political Economy 99(2), 689-721.

Frank, M. Z. \& Goyal, V. K. (2003). Testing the pecking order theory of Capital Structure. Journal of Financial Economics 67(2), 217-248

Gamba, Andrea and Triantis, Alexander J., (2008), The Value of Financial Flexibility, Journal of Finance 63(5), 2263-2296.

Gordon, Roger, and Young Lee, (2007), Interest Rates, Taxes and Corporate Financial Policies, National Tax Journal 60(1), 65-84.

Graham, John R., (2000), How Big Are the Tax Benefits of Debt? Journal of Finance 55(5), 1901-1941.

Graham, J. R. \& Harvey, C. R. (2001). The theory and practice of corporate finance: Evidence from the field. Journal of Financial Economics 60 (2-3), 187-243.

Green, Richard, and Burton Hollifield, (2003), The Personal-tax Advantages of Equity, Journal of Financial Economics 67(2), 175-216.

Harris, M. and Raviv, A. (1991). The Theory of Capital Structure. The Journal of Finance. 46 (1) 297-355

Jain, Bharat, and Omesh Kini, (1994), The Post-Issue Operating Performance of IPO Firms, Journal of Finance 49(5), 1699-1726.

Jensen, Michael C., (1986), Agency Costs of Free Cash Flow, Corporate 
Finance, and Takeovers, American Economic Review 76(2), 323-329.

Jensen, Michael C., and William H. Meckling, (1976), Theory of the Firm: Managerial Behavior, Agency Costs and Ownership Structure, Journal of Financial Economics 3(4), 305-360.

Klein, Linda Schmid, O’Brien, Thomas J. and Peters, Stephen R (2002), Debt vs. Equity and Asymmetric Information: A Review. The Financial Review 37(3), 317350.

Kraus, Alan, and Robert H. Litzenberger, (1973), A State-preference Model of Optimal Financial Leverage, Journal of Finance 28(4), 911-922.

Leary, Mark T., and Michael R. Roberts, (2010), The Pecking Order, Debt Capacity, and Information Asymmetry, Journal of Financial Economics 95(6), 332-355.

Lemmon, Michael L., and Jaime F. Zender, (2010), Debt Capacity and Tests of Capital Structure Theories, Journal of Financial and Quantitative Analysis 45, 1161 $-1187$.

Lin, M., NR Prabhala, and S Viswanathan (2009). Judging Borrowers by the company they keep: social networks and adverse selection in online Peer-to-Peer lending. SSRN working paper.

http://papers.ssrn.com/sol3/papers.cfm?abstract_id=1355679

Loughran, Tim, and Jay R. Ritter, (1997), The Operating Performance of Firms Conducting Seasoned Equity Offerings, Journal of Finance 52(5), 1823-1850.

Mertens, Donna. (1998). Research methods in education and psychology: integrating diversity with quantitative \& qualitative approaches. Sage Publications

Miglo, A. (2014). Outside debt, inside debt, start-up firms, and asymmetric information. Nipissing University working paper.

Miglo, A. (2012a). Managers vs. students: new approach in improving capital structure education. Journal of Education and Vocational Research 3(11), 353-369.

Miglo, A. (2012b). Multi-stage investment, long-term asymmetric information and pecking-order theory revisited. Journal of Current Issues in Finance, Business and Economics 4(4), 331-348.

A. Miglo (2011) Chapter 10 "Trade-Off, Pecking Order, Signaling, and Market Timing Models". in H. Kent Baker, Gerald S. Martin Capital Structure and Corporate Financing Decisions: Theory, Evidence, and Practice. (Wiley and Sons) Mar 31, pp 171-191.

Miglo, A. (2010a). The Pecking Order, Trade-off, Signaling, and MarketTiming Theories of Capital Structure: a Review. working paper. http://mpra.ub.unimuenchen.de/46691/

Miglo, A. (2010b). Capital Structure Theory: Where Do We Stand After Crisis? working paper.

Miglo, A. (2007). Debt-equity choice as a signal of earnings profile over time. Quarterly Review of Economics and Finance (Elsevier) 47 (1), 69-93

Mikkelson, Wayne H., M. Megan Partch, and Kshitij Shah, (1997), Ownership and Operating Performance of Companies that Go Public, Journal of Financial Economics 44(2), 281-307.

Modigliani, Franco, and Merton H. Miller, (1958), The Cost of Capital, 
Corporate Finance and the Theory of Investment, American Economic Review 48(3), 261-297.

Molina, Carlos A., (2005), Are Firms Underleveraged? An Examination of the Effect of Leverage on Default Probabilities, Journal of Finance 60(3), 1427-1459.

Myers, Stewart C., (1977), Determinants of Corporate Borrowing, Journal of Financial Economics 5(2), 147-175.

Myers, Stewart C., and Nicolas S. Majluf, (1984), Corporate Financing and Investment Decisions When Firms Have Information That Investors Do Not Have, Journal of Financial Economics 13(2), 187-221.

Robb, A.M. and D.T. Robinson, (2012), The capital structure decisions of new firms, The Review of Financial Studies 1(1), 1-27.

Ross, Stephen A., (1977), The Determination of Financial Structure: The Incentive Signaling Approach, Bell Journal of Economics 8(1), 23-40.

Sarbanes-Oxley Act, (2004), Available at http://www.gpo.gov/fdsys/pkg/PLAW-107publ204/pdf/PLAW-107publ204.pdf.

Shah, Kshitij, (1994), The Nature of Information Conveyed by Pure Capital Structure Changes, Journal of Financial Economics 36(2), 89-126.

Shyam-Sunder, Lakshmi, and Stewart C. Myers, (1999), Testing Static Tradeoff against Pecking Order Models of Capital Structure, Journal of Financial Economics 51(2), 219-244.

Singleton, R., Straits, B. C., \& Straits, M. M. (1993). Approaches to social research. New York, Oxford University Press.

\section{Appendix}

Appendix 1. The list of companies

\begin{tabular}{|l|l|l|l|l|}
\hline & Company & Ticker & $\begin{array}{l}\text { Long-Term } \\
\text { Debt (in \$US } \\
\text { thousands) }\end{array}$ & $\begin{array}{l}\text { Market } \\
\text { Capitalization (in } \\
\text { \$US millions) }\end{array}$ \\
\hline 1 & Accelerize New Media, lnc. & ACLZ & 480.31 & 26.2 \\
\hline 2 & Akamai Technologies, lnc. & AKAM & 0 & 6600 \\
\hline 3 & Ancestry.com lnc. & ACOM & 0 & 1300 \\
\hline 4 & AOL lnc. & AOL & 108400 & 3400 \\
\hline 5 & Atrinsic, lnc. & ATRNQ & 4020 & 16.6 \\
\hline 6 & Autobytel lnc. & ABTL & 500 & 34.9 \\
\hline 7 & Baidu, lnc. & BIDU & 452980 & 39500 \\
\hline 8 & Bankrate, lnc. & RATE & 193770 & 1100 \\
\hline 9 & Biozone Pharmaceuticals, lnc. & BZNE & 5530 & 104.7 \\
\hline 10 & Bitauto Holdings Limited & BITA & 0 & 197.2 \\
\hline 11 & Blucora, lnc. & BCOR & 74580 & 714.4 \\
\hline 12 & CafePress lnc. & PRSS & 2940 & 97.2 \\
\hline 13 & China Finance Online Co., Ltd & JRJC & 21140 & 27.5 \\
\hline 14 & ChinaCache International Holdi & CCIH & 272.72 & 109.9 \\
\hline 15 & Ediets.com lnc. & DIET & 1010 & 18.9 \\
\hline
\end{tabular}




\begin{tabular}{|c|c|c|c|c|}
\hline 16 & Facebook, lnc. & FB & 706000 & 40700 \\
\hline 17 & Firefish, lnc. & FRFS & 53.85 & N/A \\
\hline 18 & FrogAds, lnc. & FROG & 361.87 & N/A \\
\hline 19 & Global Sources Ltd. & GSOL & 0 & 188.6 \\
\hline 20 & Google lnc. & GOOG & 7890000 & 223500 \\
\hline 21 & Groupon, lnc. & GRPN & 0 & 3200 \\
\hline 22 & Healthstream lnc. & HSTM & 0 & 742.3 \\
\hline 23 & HomeAway, lnc. & AWAY & 0 & 2100 \\
\hline 24 & IAC/InterActiveCorp & IACI & 95840 & 4600 \\
\hline 25 & Immediatek lnc. & IMKI & 5.7 & 24.6 \\
\hline 26 & Internet Media Services, lnc. & ITMV & 570.67 & 0.2 \\
\hline 27 & Interxion Holding NV & INXN & 333700 & 1500 \\
\hline 28 & Jiayuan.com International Ltd. & DATE & 0 & 197.1 \\
\hline 29 & Kayak Software Corporation & KYAK & 0 & 1200 \\
\hline 30 & Kiwibox.Com, lnc. & KIWB & 8860 & 6.8 \\
\hline 31 & Linkedln Corporation & LNKD & 0 & 11300 \\
\hline 32 & LiveDeal, lnc. & LIVE & 129.94 & 9.2 \\
\hline 33 & Local Corporation & LOCM & 8000 & 59.4 \\
\hline 34 & LookSmart, Ltd. & LOOK & 313 & 14 \\
\hline 35 & Medient Studios, lnc. & MDNT & 3.5 & 1.8 \\
\hline 36 & MeetMe, lnc. & MEET & 11880 & 147.3 \\
\hline 37 & Mister Goody, lnc. & MSGO & 0 & 9 \\
\hline 38 & MMRGlobal, lnc. & MMRF & 3440 & 8.7 \\
\hline 39 & Monster Offers & MONT & 49.5 & 6.3 \\
\hline 40 & Move, lnc. & MOVE & 0 & 319.2 \\
\hline 41 & Net Savings Link, lnc. & NSAV & 222.34 & N/A \\
\hline 42 & OpenTable, lnc. & OPEN & 0 & 985.2 \\
\hline 43 & Options Media Group Holdings & OPMG & 1220 & 2.1 \\
\hline 44 & PeopleString Corporation & PLPE & 0 & 0.8 \\
\hline 45 & Phoenix New Media Limited & FENG & 0 & 288.3 \\
\hline 46 & Reach Messaging Holdings, lnc. & RCMH & 264.87 & N/A \\
\hline 47 & Rediff.com India Limited & REDF & 0 & 109 \\
\hline 48 & Remark Media, lnc. & MARK & 464.21 & 10.2 \\
\hline 49 & Renren lnc. & RENN & 0 & 1300 \\
\hline 50 & Shutterfly, lnc. & SFLY & 0 & 1100 \\
\hline 51 & Sohu.com lnc. & SOHO & 0 & 1500 \\
\hline 52 & SouFun Holdings Ltd. & SFUN & 270570 & 1400 \\
\hline 53 & SpectrumDNA, lnc. & SPXA & 9.09 & 0.7 \\
\hline 54 & Subaye, lnc. & SBAY & 0 & N/A \\
\hline 55 & SurePure, lnc. & SURP & 0 & 40.6 \\
\hline 56 & Synacor, lnc. & SYNC & 5140 & 165.4 \\
\hline 57 & Sync2 Networks Corp & SYNW & 807.98 & N/A \\
\hline 58 & TechTarget, lnc. & TTGT & 0 & 199 \\
\hline 59 & Theglobe.com lnc. & TGLO & 500 & N/A \\
\hline 60 & TheStreet, lnc. & TST & 0 & 51.6 \\
\hline 61 & Travelzoo lnc. & TZOO & 0 & 286.5 \\
\hline 62 & TripAdvisor lnc. & TRIP & 414360 & 4300 \\
\hline 63 & Tucows lnc. & TCX & 4000 & 53.7 \\
\hline
\end{tabular}




\begin{tabular}{|l|l|l|l|l|}
\hline 64 & Vacation Home Swap, lnc. & VCHS & 35.73 & 2.06 \\
\hline 65 & ValueClick, lnc. & VCLK & 172500 & 1200 \\
\hline 66 & Web.com Group, lnc. & WWWW & 694780 & 817.7 \\
\hline 67 & WebXU, lnc. & WBXU & 2310 & 7.1 \\
\hline 68 & Yahoo! Lnc. & YHOO & 39000 & 18760 \\
\hline 69 & Yelp, lnc. & YELP & 0 & 1500 \\
\hline 70 & Youku Tudou lnc. & YOKU & 2070 & 2300 \\
\hline 71 & Zynga, lnc. & ZNGA & 100000 & 1800 \\
\hline
\end{tabular}

Appendix 2. Input data (example).

\begin{tabular}{|l|c|}
\hline & \\
\hline Earnings before interest, taxes and depreciation & $\$ 1,756.00$ \\
\hline Depreciation and Amortization & $\$ 323.00$ \\
\hline Number of shares outstanding & $1,080,000,000$ \\
\hline Market price per share & $\$ 0.0000263400$ \\
\hline Beta of the stock & 1.70 \\
\hline Book value of debt & $\$ 1,432.00$ \\
\hline The market value of debt & $\$ 1,432.00$ \\
\hline Do you have any operating leases? & Yes \\
\hline Current long-term government bond rate & $2.78 \%$ \\
\hline Short-term interest rate & $1.80 \%$ \\
\hline Risk premium & $11.90 \%$ \\
\hline Country default spread & $0.00 \%$ \\
\hline
\end{tabular}

Appendix 3. Lease obligations (example)

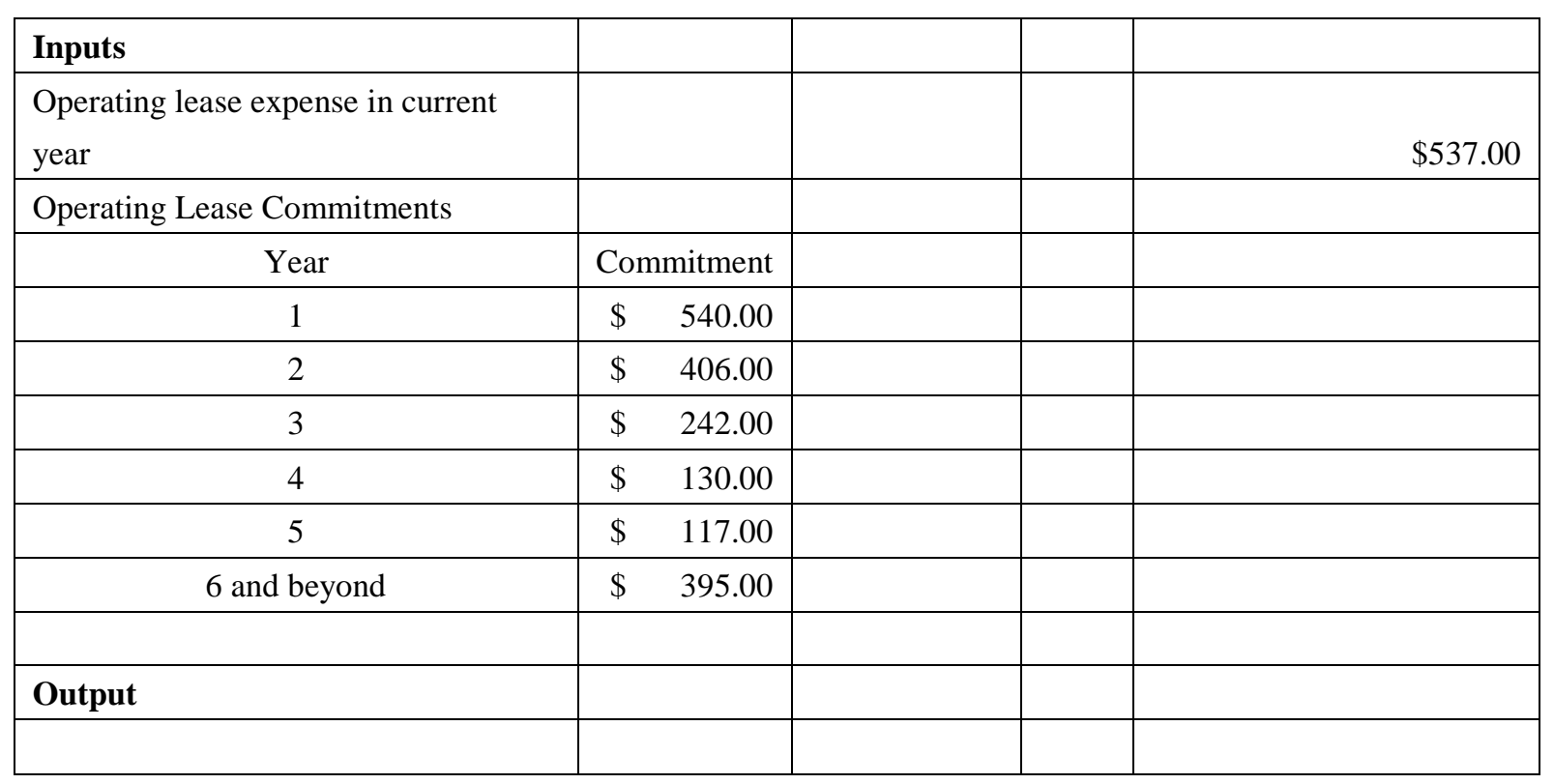




\begin{tabular}{|l|r|r|r|l|l|}
\multicolumn{1}{|c|}{ Year } & Commitment & Present Value & & \\
\hline & 1 & $\$ 540.00$ & $\$ 540.00$ & & \\
\hline 2 & $\$ 4406.00$ & $\$ 406.00$ & & \\
\hline 3 & $\$$ & 242.00 & $\$ 242.00$ & & \\
\hline 4 & $\$ 130.00$ & $\$ 130.00$ & & \\
\hline & 5 & $\$ 117.00$ & $\$ 117.00$ & & \\
\hline 6 and beyond & $\$$ & $\$ 395.00$ & $\$ 146.30$ & & \\
\hline Debt Value of leases $=$ & & & $\$ 1,581.30$ & & \\
\hline
\end{tabular}

Appendix 4. Debt Analysis (example)

\begin{tabular}{|l|r|r|}
\hline Bank medium-term debt & 899 & 899 \\
\hline Bank long-term debt & 398 & 398 \\
\hline Bonds & 0 & 0 \\
\hline $\begin{array}{l}\text { Unsecured debentures and } \\
\text { notes }\end{array}$ & 0 & 0 \\
\hline Senior debt securities & 0 & 0 \\
\hline Senior medium-term notes & 0 & 0 \\
\hline $\begin{array}{l}\text { Subordinated medium-term } \\
\text { notes }\end{array}$ & 0 & 0 \\
\hline Other notes & 135 & 135 \\
\hline Total & 1432 & 1432 \\
\hline
\end{tabular}

Appendix 5. Tax rate (example)

Facebook's TAX RATE

\begin{tabular}{|l|r|r|r|}
\hline Quarter & $\mathbf{2 0 1 2 / 9 / 2 9}$ & $\mathbf{2 0 1 2 / 6 / 3 0}$ & $\mathbf{2 0 1 2 / 3 / 3 0}$ \\
\hline Earnings before tax & -383 & 382 & 520 \\
\hline Provision for taxes & 48 & 177 & 218 \\
\hline Tax rate & $-12.53 \%$ & $46.34 \%$ & $41.92 \%$ \\
\hline Average tax rate, Tc & $25.24 \%$ & & \\
\hline
\end{tabular}


Appendix 6. Calculations (example)

\begin{tabular}{|c|c|c|c|c|c|c|c|}
\hline Table 4 & & & & & & & \\
\hline $\mathrm{D} /(\mathrm{D}+\mathrm{E})$ & D/E & Debt & Beta & Cost of Equity & $\begin{array}{c}\text { Operating } \\
\text { Inc. }\end{array}$ & Depreciation & Interests \\
\hline $0.00 \%$ & $0.00 \%$ & 0.00 & 1.57 & $20.50 \%$ & $\$ 1,756$ & $\$ 323$ & $\$ 0$ \\
\hline $5.00 \%$ & $5.26 \%$ & 1561.63 & 1.63 & $21.23 \%$ & $\$ 1,756$ & $\$ 323$ & $\$ 52$ \\
\hline $10.00 \%$ & $11.11 \%$ & 3154.76 & 1.70 & $22.05 \%$ & $\$ 1,756$ & $\$ 323$ & $\$ 104$ \\
\hline $15.00 \%$ & $17.65 \%$ & 4780.35 & 1.78 & $22.96 \%$ & $\$ 1,756$ & $\$ 323$ & $\$ 158$ \\
\hline $20.00 \%$ & $25.00 \%$ & 6439.40 & 1.86 & $23.99 \%$ & $\$ 1,756$ & $\$ 323$ & $\$ 213$ \\
\hline $25.00 \%$ & $33.33 \%$ & 8132.96 & 1.96 & $25.16 \%$ & $\$ 1,756$ & $\$ 323$ & $\$ 268$ \\
\hline $30.00 \%$ & $42.86 \%$ & 9816.45 & 2.07 & $26.49 \%$ & $\$ 1,756$ & $\$ 323$ & $\$ 363$ \\
\hline $35.00 \%$ & $53.85 \%$ & 11517.44 & 2.20 & $28.02 \%$ & $\$ 1,756$ & $\$ 323$ & $\$ 461$ \\
\hline $40.00 \%$ & $66.67 \%$ & 13232.66 & 2.35 & $29.82 \%$ & $\$ 1,756$ & $\$ 323$ & $\$ 562$ \\
\hline $45.00 \%$ & $81.82 \%$ & 14951.52 & 2.53 & $31.93 \%$ & $\$ 1,756$ & $\$ 323$ & $\$ 673$ \\
\hline $50.00 \%$ & $100.00 \%$ & 16587.48 & 2.75 & $34.48 \%$ & $\$ 1,756$ & $\$ 323$ & $\$ 829$ \\
\hline $55.00 \%$ & $122.22 \%$ & 18380.03 & 3.01 & $37.58 \%$ & $\$ 1,756$ & $\$ 323$ & $\$ 919$ \\
\hline $60.00 \%$ & $150.00 \%$ & 19961.29 & 3.33 & $41.47 \%$ & $\$ 1,756$ & $\$ 323$ & $\$ 1,098$ \\
\hline $65.00 \%$ & $185.71 \%$ & 21762.25 & 3.75 & $46.46 \%$ & $\$ 1,756$ & $\$ 323$ & $\$ 1,197$ \\
\hline $70.00 \%$ & $233.33 \%$ & 23262.71 & 4.31 & $53.11 \%$ & $\$ 1,756$ & $\$ 323$ & $\$ 1,396$ \\
\hline $75.00 \%$ & $300.00 \%$ & 24338.67 & 5.10 & $62.43 \%$ & $\$ 1,756$ & $\$ 323$ & $\$ 1,704$ \\
\hline $80.00 \%$ & $400.00 \%$ & 26047.03 & 6.27 & $76.41 \%$ & $\$ 1,756$ & $\$ 323$ & $\$ 1,823$ \\
\hline $85.00 \%$ & $566.67 \%$ & 26886.25 & 8.23 & $99.71 \%$ & $\$ 1,756$ & $\$ 323$ & $\$ 2,151$ \\
\hline $90.00 \%$ & $900.00 \%$ & 27578.94 & 12.14 & $146.30 \%$ & $\$ 1,756$ & $\$ 323$ & $\$ 2,482$ \\
\hline $95.00 \%$ & $1900.00 \%$ & 29096.43 & 23.89 & $286.08 \%$ & $\$ 1,756$ & $\$ 323$ & $\$ 2,619$ \\
\hline \multicolumn{8}{|c|}{ 5. MAIN RESULTS } \\
\hline \multicolumn{8}{|l|}{ Table 5} \\
\hline & $\begin{array}{l}\mathrm{D} /(\mathrm{D}+\mathrm{E}) \\
\text { Ratio }\end{array}$ & & $\begin{array}{l}\text { Beta for the } \\
\text { Stock }\end{array}$ & Cost of Equity & Cost of Debt & & WACC \\
\hline $\begin{array}{l}\text { Current } \\
\text { capital } \\
\text { structure }\end{array}$ & $9.88 \%$ & & 1.70 & $22.03 \%$ & $2.30 \%$ & & $20.08 \%$ \\
\hline $\begin{array}{l}\text { Optimal } \\
\text { capital } \\
\text { structure }\end{array}$ & $65.00 \%$ & & 3.75 & $46.46 \%$ & $4.11 \%$ & & $18.93 \%$ \\
\hline Change & $55.12 \%$ & & 2.05 & $24.43 \%$ & $1.81 \%$ & & $-1.15 \%$ \\
\hline
\end{tabular}

